This item was submitted to Loughborough's Research Repository by the author.

Items in Figshare are protected by copyright, with all rights reserved, unless otherwise indicated.

\title{
Hegel's geographical thought
}

PLEASE CITE THE PUBLISHED VERSION

https://doi.org/10.1068/d19112

\section{PUBLISHER}

SAGE Publications $@$ Pion

\section{VERSION}

AM (Accepted Manuscript)

\section{PUBLISHER STATEMENT}

This work is made available according to the conditions of the Creative Commons Attribution-NonCommercialNoDerivatives 4.0 International (CC BY-NC-ND 4.0) licence. Full details of this licence are available at: https://creativecommons.org/licenses/by-nc-nd/4.0/

\section{LICENCE}

CC BY-NC-ND 4.0

\section{REPOSITORY RECORD}

Bond, Dean W.. 2019. “Hegel's Geographical Thought”. figshare. https://hdl.handle.net/2134/32025. 
Original Word Count: 9,830

Revised Word Count: 11,253

\begin{abstract}
This paper sketches out the contours of the philosopher G.W.F. Hegel’s (1770-1831)

geographical thought. Until now, geographers have shown little interest in Hegel's geographical thought. He has figured minimally in histories of geography, and critical geographers who have engaged with Hegel have done so indirectly, either through Marx’s work or through Marxist and postcolonial scholars’ readings of Hegel. This paper offers a more direct reading. It begins from an understanding of geographical thought as both an intellectual and practical endeavour with its own distinct historical geographies. It examines Hegel's concepts of 'nature' (Natur) and 'space' (Raum); his understanding of geography’s relationship to history and anthropology; his relationship to Carl Ritter (1779-1859) and Alexander von Humboldt (1769-1859); and the significance of 'territory' in his political philosophy. It highlights the ambiguity that characterized Hegel's thinking about geography, especially in his discussion of climate’s influence on humans. It also challenges Henri Lefebvre's reading of Hegel's view on the state’s relationship to territory. Finally, it suggests that Hegel’s conceptions of nature, space and geography mattered not only for his philosophies of history, nature and subjective spirit, but for his understanding of modernity’s geographies as well.
\end{abstract}

Keywords: G.W.F. Hegel, historical geography, philosophy of geography, space, territory 


\section{Introduction}

The philosopher G.W.F. Hegel (1770-1831) has long remained on geography’s disciplinary periphery. Histories of geographical thought have either left Hegel out or simply referred to him in passing. More than historians of geography, Marxist and critical geographers more broadly have given Hegel a disciplinary presence through discussions of dialectics and Hegel's influence on Marx. Still, geographers have devoted less attention to Hegel than to his forerunner and sometime adversary Immanuel Kant (1724-1793), whose lectures on physical geography Richard Hartshorne helped bring to Anglophone geographers' attention in The Nature of Geography (1939). That Kant has garnered more attention than Hegel is not surprising, since Kant lectured on physical geography forty-nine times between 1756 and 1796 and exhibited a deep interest in the subject, while Hegel never devoted an entire lecture course to geography (see Elden, 2009; Kant, 2009; Elden and Mendieta, 2011; Stark, 2011).

Though Hegel exhibited a weaker commitment to geography than Kant, he discussed geography in his many of his lectures at Berlin University, where he had taken up a chair in philosophy in 1818. In his Vorlesungen über die Philosophie der Weltgeschichte [Lectures on the Philosophy of World History], he laid out history’s ‘geographical foundation’ (geographische Grundlage), ${ }^{1}$ while his Vorlesungen über die Philosophie des subjektiven Geistes [Lectures on the Philosophy of Subjective Spirit] (1822/25-1827/28) contained related remarks on

\footnotetext{
${ }^{1}$ While translators of Hegel's lectures on the philosophy of world history have typically rendered Grundlage as 'basis', I translate Grundlage as ‘foundation'. I do so because Hegel’s use of Grundlage reflected in part his engagement with Immanuel Kant, one of Hegel's primary interlocutors, who also employed the term Grundlage and its cognate Grundlegung ('groundwork'). In Kant's case, Grundlage is better rendered as ‘foundation' than 'basis', and thus I opt for 'foundation' to retain the Kantian overtones Grundlage harbours. For Kant's use of Grundlage and cognate terms, see for example Kant (1968b). I thank an anonymous referee for highlighting the Kantian resonance in Hegel's use of Grundlage.
} 
geography's relationship to spirit's development. ${ }^{2}$ Likewise, space featured prominently in Hegel's Vorlesungen über die Philosophie der Natur [Lectures on the Philosophy of Nature] $(1819 / 20-1825 / 26) .^{3}$

Philosophers have paid more attention than geographers to Hegel's remarks on space and geography in his lectures and Encyclopedia of the Philosophical Sciences (1817-1830). Yet, philosophers have often treated Hegel’s geographical ideas as a secondary concern within broader investigations. As a result, an overarching synthesis of Hegel's geographical thought remains lacking.

In this paper I provide an introductory sketch of Hegel's 'geographical thought' as a whole. I suggest that Hegel's Berlin lectures on nature, spirit and history, delivered with his infamous stutter, Schwäbian accent and accompanying hand gestures, not only "firmly cemented his celebrity in Berlin” (Pinkard, 2000, page 494; also see Rosenkranz, 1963 [1844], page 360), but also expressed the fundamental character and contours of his geographical thought. I define Hegel's 'geographical thought' as his ideas about space, place and human-environment relations more generally, and work from a broad understanding of geography as a ‘contested tradition’ of ideas and practices concerning the earth’s surface and humans' relationship to it (see Livingstone, 1992; 1995; also Driver, 1992; Gregory, 1994). And, while I recognize that distinct historical geographies and power relations have always undergirded geography's contested practices and ideas, here I primarily focus on Hegel's ideas, while paying some attention to his biography.

\footnotetext{
${ }^{2}$ Geist, a crucial term in Hegel's philosophy, has often caused Hegel's translators difficulty. Geist can be translated as "spirit” or "mind”, and translators have employed both. Stone (2005) has argued that "whereas 'mind' captures better the rational, conceptual, and thinking aspects of Geist, 'spirit' better captures its cultural, historical, and collective dimension” (page 172, note 14). Here, I translate Geist as 'spirit'.

${ }^{3}$ Like Kant's lectures on physical geography (see Stark, 2011), the published editions of Hegel's lectures derive from students' notes. For background on the lectures on nature, right, and world history, see the editors' commentary in Hegel (1996; 2000; 2002; 2007).
} 
Hegel's geographical thought deserves attention for three reasons. First, an investigation of Hegel's geographical thought contributes to our understanding of modern geographical thought's messy and contested trajectory. Second, thinking about Hegel's philosophy geographically suggests that, in many ways, his philosophies of world history and 'right' (Recht) constituted an interpretation of modernity's historical geography. Third, Hegel's geographical thought deserves attention because it highlights a certain tension in his thinking about humans' ability to become progressively more self-conscious and free.

In what follows, I first review geographers' limited engagement with Hegel’s geographical thought and philosophy more broadly. I focus on geographers rather than philosophers in my review because I see this paper as an intervention in the history of geography in the broadest sense, rather than an intervention in the history of philosophy. After reviewing geographers' remarks on Hegel, I briefly discuss Hegel's social ties with his contemporaries Carl Ritter (17791859) and Alexander von Humboldt (1769-1859) to provide some biographical and intellectual context for the discussion that follows. I then address the three primary geographical facets of Hegel's work, namely his concept of 'space', his understanding of physical geography and its relation to race and history, and finally territory's significance in his political philosophy.

\section{Hegel among the geographers}

Hegel has remained absent from most work on the history of geography, especially those histories written from a discipline-centred perspective (e.g. Beck, 1973; Martin, 2004). Otherwise, Hegel has received only passing mention. For example, in The Makers of Modern Geography (1969), Dickinson simply remarked, "Humboldt shared the philosophic views of his era, as expressed by Hegel and Goethe” (page 23). In histories written from a broader 
understanding of geography's history, Hegel has likewise garnered little attention. For example, Glacken (1967) associated Hegel with the notion of the "the geographic march of history", which “enjoyed some popularity in the nineteenth century” (page 277), while Livingstone (1992) simply acknowledged Hegel's presence in Berlin's early nineteenth century intellectual scene in his discussion of Carl Ritter’s student, Arnold Guyot (1807-1884) (page 150).

Geographers have said more about Hegel's discussion of 'geo-history'. In particular, geographers have remarked on Hegel's well-known efforts to exclude peoples in extreme climatic zones from history. As early as the late nineteenth-century, the oft-maligned German geographer Friedrich Ratzel (1844-1904) castigated Hegel in passing for his views on climate and history:

"How ungeographical [ungeographisch] these ideas are, and how they show nothing of the widening of the horizon that geographical studies must necessarily result in, and how these ideas indicate a delusion bordering on injustice against the nature of things!” (Ratzel, 1882, page 32; compare Stederoth, 2001, pages 146-147). ${ }^{4}$

Later geographers have likewise pointed to Hegel's exclusionary move, but also characterized his thoughts on climate in more nuanced ways. Geographers have acknowledged that while Hegel edged many world regions and their inhabitants to history's margins, he also proved "chary of admitting too much climatic influence on human affairs", as Livingstone (2002, page 165) has noted. Schwind (1960, pages 4-6) argued that Hegel saw geographical conditions’ effect on human development not in simple causal terms, but rather as an ongoing challenge, one which the extreme zones' inhabitants could not meet given the harsh geographical conditions they faced (also see Anunchin, 1977 [1960], page 83). In his study of Kant’s geography, May (1970) similarly asserted that while he excluded the torrid and frigid zones, Hegel "was no

\footnotetext{
${ }^{4}$ Unless otherwise noted, translations from the German are my own.
} 
simple environmental determinist” (page 43), while Mann (2008) suggested that Hegel depicted nations as “quasi-environmentally determined” (page 923, emphasis added). ${ }^{5}$

Geographers have also critiqued Hegel’s move to exclude the torrid and frigid zones from history's remit. Livingstone (2002) has suggested that Hegel's exclusionary move evidences a 'moral climatology', which he defined as a long-running tendency in Western thought "to deploy moralistic language in depicting climactic conditions and a conviction that it is entirely reasonable to read moral order straight off patterns of global climate” (page 160). In particular, Livingstone suggested that Hegel 'moralized' and 'racialized' global space in his geo-historical narrative (pages 164-165). Gregory (1998), moreover, has critiqued Hegel's geo-history from a postcolonial perspective. Whereas Livingstone (2002) suggested Hegel’s discussion evidenced his moral climatology, Gregory (1998) suggested it exemplified a Eurocentric, "postEnlightenment geographical imaginary”, which viewed Europe’s temperate geographies as 'normal' geographies, equated modernity with nature’s mastery, and erected an “absolute configuration of world Geography” on these premises (pages 76-78, 87-88).

Livingstone (2002) and Gregory’s (1998) critiques, while partly justified, require further complication. Hegel's Eurocentrism in his philosophy of world history proves difficult to dispute (e.g. Innerarity, 1992; Bernasconi, 2000; cf. McCarney, 2000, pages 145-148). That Hegel employed a morally charged vocabulary when he described Africans and indigenous groups in the Americas also proves difficult to dispute, given that he described indigenous groups in the Americas, for example, as “weakly cultivated peoples” (schwach gebildeten Völker) who had “little capacity for cultivation” (von geringer Fähigkeit zur Bildung) (Hegel, 1955, pages 201202/163-164; also 2008, pages 34-36; 2011, pages 610-612). Livingstone’s claim that Hegel

\footnotetext{
${ }^{5}$ Philsophers, too, have highlighted the ambiguity that underpins Hegel's thoughts on climate. See Walsh, (1971, pages 183-187); Bernasconi (1998, page 52; 2000, page 186); McCarney (2000, pages 143-145); Stederoth (2001, pages 146-151); Mussett (2003); cf. Günzel (2002, page 295).
} 
'racialized' global space proves more problematic, because scholars remain divided on whether Hegel's geo-history exhibited racist sentiments, ${ }^{6}$ and even those who detect racism in Hegel's geo-history have acknowledged that Hegel failed to clarify race's precise relationship to geography (Krell, 2000, pages 123-125).

In addition to his ideas about climate, geographers have engaged with aspects of Hegel's Philosophy of Right and Philosophy of Nature. Marxist geographers, who have often seen Hegel as Marx’s intellectual precursor or foil, have discussed Hegel’s influence on Marx, the relationship between Marx and Hegel's understandings of nature (Anunchin, 1977 [1960], pages 82-84; Burgess, 1978; Peet, 1998; Smith, 2008 [1984], page 78), the shortcomings of Hegel’s idealism, and the significance of capitalism and imperialism in Hegel's political philosophy (Harvey, 1981; Peet, 1985; Mann, 2008).

Harvey (1981) in particular underscored capitalism and imperialism’s significance in Hegel's political philosophy. Harvey has argued that in the Philosophy of Right, Hegel developed "the lineaments of an economic theory of capitalist imperialism”, and has suggested that Marx and Thünen’s work served in part as “answers to a problem Hegel left open -- the role of geographical expansion and territorial domination, of colonialism and imperialism, in the stabilization of capitalism” (Harvey, 1981, page 1; also Harvey, 2006 [1982], pages 414-415). Building on Harvey's argument, Mann (2008) has suggested that Hegel's remarks on colonialism and capitalist expansion prove significant because they demonstrate that Hegel, like Marx, recognized that capitalist expansion produced “real, material geographies” and "lived spatial problematics” (page 923). To be sure, Hegel’s reference to England’s incredible wealth and

\footnotetext{
${ }^{6}$ Numerous scholars have argued that Hegel's philosophy evidences racist assumptions, although scholars disagree about the precise nature of Hegel's racism (e.g. Neugebauer, 1991; Mollendorf, 1992; Bernasconi, 1998; 2000; 2003; 2011; Buck-Morss, 2000; 2009; Krell, 2000; Hoffheimer, 2001; 2005; Purtschert, 2010). Other scholars have contested the racist charge (e.g. Walsh, 1971; McCarney, 2000; 2003; Houlgate, 2005, pages 22-23; Bonetto, 2006).
} 
poverty (2000, page 145; 2009, §245 Remark), along with his claim that economic conditions in civil society lead to colonization (2000, page 147; 2009, §§247-248), suggest Hegel understood that capitalist development engendered real geographies with material consequences. ${ }^{7}$

Marxist and critical geographers more broadly have drawn Hegel into geographical debates through varied readings of Hegel’s dialectic. Harvey (1996; 1999) and Soja’s (1989; 1996) readings of Lefebvre's work in particular have figured centrally in geographers' uptake of Hegel and Marx’s dialectical thinking (see Castree, 1996; Roberts, 2001; Collinge, 2008). Moreover, Hegel has figured in recent discussions concerning less Hegelian ways to think about dialectics (e.g. Jones, 1999; Collinge, 2008; Ruddick, 2008; 2011; Sheppard, 2008). Further, Gidwani (2008) has drawn Hegel into geography through his postcolonial reading of Hegel's Phenomenology of Spirit, wherein he argued that an inherent instability and openness haunts Hegel's dialectical logic in the form of the 'subaltern', a "figure which resists or evades dialectical integration” (page 2579).

Geographers have also criticized Hegel's understanding of the state and its relationship to territory. Drawing on Lefebvre’s reading of Hegel (see Elden, 2004, pages 15-73, 211-217), Soja (1989) has argued that, “[i]n many ways, Hegel and Hegelianism promulgated a powerful spatialist ontology and phenomenology, one which reified and fetishized space in the form of the territorial state”. For Soja, Marx’s “anti-Hegelianism” revolved around “a powerful sensitivity and resistance to the assertion of space into a position of historical and social determination”, and thus entailed an “anti-spatialism”, which appeared in "virtually all of Marx’s writings” (page 86). As I argue in the paper’s final section, however, Lefebvre and Soja's suggestion that "Hegel and Hegelianism...reified and fetishized space in the form of the territorial state” proves problematic.

\footnotetext{
${ }^{7}$ Here I cannot adequately treat Hegel's views on colonialism and capitalist expansion. For arguments similar to Harvey's, see Avineri (1972, pages 132-154) and Hirschmann (1976). Compare Bernasconi (2000, pages 189-190); Hoffheimer (2001); McCarney (2000, pages 148-151).
} 
In particular, their tendency to conflate Hegel with 'Hegelianism', along with territory’s relative absence in Hegel's own work, undermines their claim that Hegel reified the 'territorial state'.

Geographers have devoted less attention to Hegel's notion of 'space'. In his article on the concept of 'necessity' in Hegel and Marx, Mann (2008) highlighted Hegel’s description of space as fixed, continuous and undifferentiated. By conceiving of space as passive and fixed, Mann has argued, Hegel removed space_-and time_-from the dialectical process (pages 924-925). Harvey (1999) has also focussed on Hegel's description of abstract space and concluded, "Hegel could not have been dialectical about space in the ways that Leibniz and Whitehead could” (page 558). Harvey thereby distanced Hegel’s ‘passive’ space from Leibniz’s relational space and Whitehead's processual space (see Casey, 1997, pages 167-179, 211-216). However, as my treatment of Hegel’s concept of 'space’ below suggests, while Hegel conceived space differently from Leibniz and Whitehead, he believed space and time emerged simultaneously and proved integral to nature’s dialectic.

\section{Hegel among the Berlin geographers: Carl Ritter and Alexander von Humboldt}

Carl Ritter figured prominently in Hegel’s geographical thought. Hegel first learned about Ritter's work after he had moved to Berlin in 1818 to take up a chair in philosophy at the recently founded Berlin University. ${ }^{8}$ He expressed his happiness with having encountered Ritter’s work in an 1819 letter to his friend Georg Friedrich Creuzer (1771-1858), a prominent philologist. There, Hegel told Creuzer he possessed preprints from Ritter’s Vorhalle europäischer Völkergeschichten vor Herodotus (1820), and expressed his admiration for Ritter’s work:

\footnotetext{
${ }^{8}$ Ritter moved from Frankfurt to Berlin in 1820 to take up posts at the Royal Military Academy and Berlin University. In 1825 he took up a chair in geography at Berlin University (Sinnhuber, 1959, page 157).
} 
“Ritter’s work, whose Geography I first learned of here and very much welcomed, I view as an important support for---and, from a higher perspective, as a fruit and consequence of---your work; his work acknowledges your merit....I hope that you recognize him as an important collaborator, though one can of course be no more than an imitator of yours in this field [i.e. philology]). ${ }^{9}$

Ritter’s Erdkunde (1817) in particular had impressed Hegel. In his 1822/23 Lectures on the Philosophy of World History, he praised "Ritter's nice work" [i.e. his Erdkunde], wherein Ritter had "thoroughly observed the physical characteristics of these continents [i.e. Africa, Asia, Europe]” (Hegel, 1996, page 97). Hegel further noted that Ritter's Erdkunde offered “the best sketch of Africa” (Hegel, 1955, page 217/176). ${ }^{10}$

Hegel not only admired Ritter’s geographical work but drew on it as well. In particular, Ritter's continental typology provided the foundation for Hegel's own geographical divisions in the lectures on the philosophy of history and subjective spirit (Stederoth, 2001, pages 129, 144145; Mussett, 2003, pages 6, 9-10). In his lectures he even invoked Ritter’s Erdinviduum concept: "In this division of the earth-individual [Erdindividuum] something necessary predominates, whose closer analysis belongs to geography” (1970b, §393 Addition, trans. modified; cf. Ritter, 1817, pages 10, 63, 296, 413, 423). Hegel's invocation of Ritter’s “Erdindividuum” raises questions about Hegel’s conceptual affiliations with Ritter. Bernasconi (1998) has suggested that Ritter and Hegel had “very different” interests (page 301, note 12), while Livingstone (2002) has argued that Hegel's geo-history constituted “an exercise in the

\footnotetext{
${ }^{9}$ Hegel to G.F. Creuzer, Berlin, 30 Oct. 1819, in Hegel (1961 II, Br. 359, page 218/450). One year later, in May 1820, Creuzer reported to Hegel from Heidelberg that he had "gotten to know Prof. Ritter personally", and described him as “an amiable man”. See G.F. Creuzer to Hegel, Heidelberg, 30 May 1820, in Hegel (1961 II, Br. 368, page 231).

${ }^{10}$ Hegel possessed the first edition of the Erdkunde's (1817) first two volumes, along with the first part of the second edition that appeared in 1818 (Neuser, 1987, page 492).
} 
universal spiritualization of space, a stance entirely in keeping with his approving resort to the geographical writings of Carl Ritter” (page 164). Stederoth (2001) has also hinted at conceptual links between Hegel and Ritter (pages 129, 144-147). Taken together, Bernasconi, Livingstone and Stedroth’s remarks suggest Ritter and Hegel's conceptual affiliations deserve more scrutiny. ${ }^{11}$

Hegel had a more complicated relationship to Alexander von Humboldt. Many contemporaries even viewed Humboldt as one of Hegel's adversaries. ${ }^{12}$ Humboldt saw some merit in Hegel's philosophy, yet he viewed Hegel's philosophical project less favourably than many contemporaries. Humboldt exemplified his feelings about Hegel’s philosophy when he “delivered a thinly veiled attack against all post-Kantian philosophy -- in other words, against Hegel, among others” in lectures on physical geography he gave after returning from his world travels in the winter of 1827/28 (Pinkard, 2000, page 610). While Hegel missed Humboldt’s lectures, his wife attended, and he later received word about the famed geographer's negative comments. ${ }^{13}$ Upset, he complained to friends, including K.A. Varnhagen von Ense, a mutual friend of Hegel and Humboldt's, who informed Humboldt of Hegel's feelings. In a strategic move, Humboldt gave Varnhagen a copy of his notes from a different lecture, which lacked any offending remarks. ${ }^{14}$ Varnhagen showed Hegel the lecture notes, and, after he had looked them over, Hegel concluded that Humboldt had not in fact attacked him. Moreover, when he returned the lecture notes to Varnhagen, he asked him to tell Humboldt that he displayed an "amiable considerateness” and “exemplary friendliness” in giving him the notes, and even praised

\footnotetext{
${ }^{11}$ A comparative study of Hegel and Ritter might also consider Ernst Kapp’s (1808-1896) work. Kapp developed a 'philosophical geography' (philosophische Erdkunde) based on Hegel’s philosophy and Ritter's geography (see Sass, 1973).

${ }^{12}$ See the English translation of Hegel's Briefe (1961), editor's commentary, pages 528-529.

${ }^{13}$ Hegel to K.A. Varnhagen von Ense, Berlin, 24 Nov. 1827, in Hegel (1961 III, Br. 570, pages 211-212/530; also see Hegel to Cousin, [Berlin], 3 March 1828, in Hegel (1961 III, Br. 575, page 223/666).

${ }^{14}$ Humboldt to K.A. Varnhagen von Ense, Berlin, 21 Nov. 1827, in Humboldt (1860, Br. 3, page 3/19).
} 
Humboldt as "a scholar who both embraces empirical knowledge in all its wealth and connects this wealth to universal ideas”. ${ }^{15}$

Humboldt also attacked Hegel's geographical descriptions. A recognized expert on South America, Humboldt found fault with Hegel's discussion of America and the 'Indian World' (die indische Welt) in his Lectures on the Philosophy of History, which had appeared for the first time in print in 1837. That year, Humboldt remarked in a letter to his friend Varnhagen:

“...but a man who is as I am, like an insect, inseparable from the earth [Boden] and its natural variations [Naturverschiedenheiten], feels himself uneasy and constrained at an abstract assertion of totally inaccurate facts and views on America and the Indian world. At the same time I do not fail to recognize what is brilliant in Hegel's work". ${ }^{16}$

For Humboldt, then, Hegel’s geographical descriptions of the New World had little credibility, and his philosophical project had little more.

The structure of Hegel's Encyclopedia

To understand Hegel's geographical thought, it is important to first briefly outline his philosophical project's overarching structure as expressed in his Enycylopedia of the Philosophical Sciences. The Encyclopedia contained three parts, namely the Logic (§§19-244), the Philosophy of Nature (§§245-376) and the Philosophy of Spirit (§§377-577). Moving from the most abstract sphere (Logic) to the most concrete (Spirit), Hegel traced the process wherein spirit comes to know itself as self-determining reason. He further divided each of the

\footnotetext{
${ }^{15}$ Hegel to K.A. Varnhagen von Ense, Berlin, 24 Nov. 1827, in Hegel (1961 III, Br. 570, pages 211-212, quote at 212/530-531, quote at 530); also Pinkard (2000, pages 609-610).

${ }^{16}$ Humboldt to K.A. Varnhagen von Ense, 1 July 1837, in Humboldt (1860, Br. 30, page 44/59, trans. modified). For critical analyses of Hegel's description of the Americas, see Hoffheimer (2001) and Parekh (2009). On Hegel and Humboldt's work on America and its place in 'the dispute of the New World', see Gerbi (2010 [1955], pages 402441).
} 
Encyclopedia's three sections into three parts, which likewise proceeded from the most abstract to the most concrete, according to spirit’s immanent progression as self-determining reason. Each of the Enyclopedia's sections expressed a moment in spirit's coming to know itself and must be understood in relation to one another.

Space, physical geography, geo-history and 'race' (Rasse, Geschlecht) appear in the Enyclopedia's second and third parts. Hegel divided the Philosophy of Nature into mechanics, physics, and organics, and treated ‘space’ under mechanics (§§254-256). Physical geography fell under 'organics'. The Philosophy of Spirit, which traced spirt's immanent progression through increasingly higher stages of self-realization and freedom, subdivided into subjective spirit, which concerned consciousness’ nature and development (§§387-482), objective spirit, which concerned 'right' (Recht), 'morality’ (Moralität) and 'ethical life’ (Sittlichkeit) (§§483-551), and absolute spirit, which dealt with art, religion and philosophy (§§553-577). Hegel treated geography's relation to racial differences under 'subjective spirit'. His remarks on geography in the Philosophy of Spirit, moreover, rested on his brief discussion of physical geography in the Philosophy of Nature (§339 Addition), ${ }^{17}$ and in turn helped structure his discussion of geography in the Philosophy of Right and Philosophy of World History.

\section{Hegel's concept of 'space' (Raum)}

Hegel's discussion of space and his philosophy of nature more generally reflected his longstanding interest in the physical sciences. His sister reported that physics and mathematics counted among Hegel's favourite subjects in his early years (Pinkard, 2000, page 562). His Habilitation thesis, Dissertatio philosophica de orbitis planetarum (1801), concerned planetary

\footnotetext{
${ }^{17}$ Paragraph numbers (§) here refer to the Encylcopedia’s third addition of 1830 (Hegel, 1992a). Additions (Zusätze) in Hegel's texts stemmed from students' lecture notes, and some scholars see the Zusätze as problematic. Zusätze should be handled with care and cross-referenced whenever possible.
} 
orbits (Houlgate, 2005, pages 114-115). His Encyclopaedia testified to his “wide-ranging interest and erudition regarding topics in physics, optics, chemistry, geology, biology, and the like” (Pinkard, 2000, page 562; see also Petry, 1981, pages 614-615). Hegel lectured on the natural sciences in Heidelberg and Berlin (Petry, 1981, page 616), exhibited familiarity with contemporary scientific periodicals (Petry, 1970, pages 48-49), and counted many prominent natural scientists among his friends. He also had links with scientific societies in Jena, Westphalia and Heidelberg, though he was refused admission to the Berlin Academy of Sciences (Rosenkranz, 1963 [1844], page 220; Pinkard, 2000, pages 446-447).

Hegel's treatment of space also reflected his understanding that any comprehensive philosophy had to define space’s nature and properties (1970a, §254 Addition). Indeed, discussions of space, time and place's nature, along with their significance for human being's ontological constitution and subjective experience of the sensible world, figured into most philosophical treatises on metaphysics. Most philosophers agreed that space, time and place mediated man's grasp of the world, though they described their nature and function in different ways (see Casey, 1997).

Hegel discussed 'space' under the first level in his philosophy of nature, namely "mechanics", which concerned "matter in so far as it is characterized by different forms of motion than can be described mathematically” (Hegel, 1992a, §§254-261; cf. 2006, pages 312315). Here, he argued that space, as 'sheer externality', must be conceived as abstract and ideal for it to serve as nature's logical foundation. More specifically, space must be conceived as absolute, immediately equivalent, continuous, fixed and undifferentiated (1992a, §254-255; also 2006, pages 312-315; 2008, pages 440-441, 580-581; 2011, page 815). 
Absolute space allowed for the possible determination of equivalent points or 'heres', and formed a 'pure quantity' (reine Quantität), that is, an entity lacking determinate differences in itself (1992a, §§100, 254 Remark). Hegel further argued that this originary absolute space must be conceived as unbounded and undifferentiated, because beginning from a bounded, already internally differentiated space would logically presume that an even more foundational ‘absolute’ or 'abstract’ space exists (Hegel, 1999a, §254; 1970a, §254 Addition). ${ }^{18}$ Thus, for Hegel, nature's logical foundation had to rest in an unbounded and internally undifferentiated space, which logically followed only from itself. ${ }^{19}$

Yet, while Hegel argued that nature logically began with 'abstract' space, he did not valorize abstract space or see it as separable from time (Zeit). Abstract space contained within itself its own negation, namely time. Indeed, to progress beyond space as nature’s first stage, nature's logic dictated that space must negate and supersede itself. Time logically emerged from abstract space and negated it. In turn, determinate 'points' and 'places' sublated abstract space and time. In other words, abstract space's negation by time gave rise to materially determined points, lines and places, and ultimately ‘motion’ (1992a, §§257-261; 2002, pages 19-29).

While absolute space constituted nature's 'foundation', it did not constitute its 'truth'. Consequently, Hegel argued against those who saw absolute space as space's ultimate form: "Some think that this [absolute space] is the truth of space. Yet relative space is something much higher, because it is the spatial determination of some material body” (1970a, §254 Addition, emphasis added). Absolute space by itself could not serve as space's 'truth', because it necessarily belonged to the dialectical movement engendered by nature's own internal logic.

\footnotetext{
${ }^{18}$ Hegel used the terms 'absolute' and 'abstract' interchangeably (e.g. 2002, page 15; 2006, §13)

${ }^{19}$ While I refer here to Hegel's Encyclopedia, see also Hegel's discussions of space and time in his Lectures on the Philosophy of Nature (2002, pages 13-26; 2007, pages 35-53).
} 
How, then, did Hegel's notion of space compare with other predominant notions within the philosophical tradition? In contrast to John Locke, David Hume and Gottfried Wilhelm Leibniz (see Casey, 1997, pages 162-179), Hegel rejected the claim that space’s concept and very existence could be abstracted from one’s sense perception of a given space, or relations among entities in a given space (Hegel, 1970a, §254 Addition; Jenkins, 2010, page 329-332). Hegel agreed with Kant, who, in his effort to refute Locke, Hume and Leibniz’s circular reasoning about space, argued that the perception of spatial relations already presumed some representation and prior understanding of space, and thus could not originate in our sense experience of those same spatial relations (Hegel, 1970a, §254 Addition; Jenkins, 2010, pages 329-332). For Kant, our 'representation' (Vorstellung) of space must instead be an a priori form of 'intuition' (Anschauung), which, along with time, forms the ground for all sense experience, including our experience of spatial relations (Kant, 1998 [1781/87], A23-30/B38-45; cf. Hegel, 1970a, §254 Remark \& Addition; 2002, pages 13-14; 2008, pages 438-440). ${ }^{20}$

Hegel thought Kant's transcendental deduction of space and time fell short, however, since Kant failed to explain why space and time constitute the only possible forms of intuition. For Hegel, Kant failed to see that space and time could be "derived from a more basic notion” than his a priori forms of intuition (Jenkins, 2010, page 334). For Hegel, space logically existed prior to perceiving subjects' a priori intuition of space and time, and thus he rejected Kant's claim that one can only speak of space “from a human standpoint” (Kant, 1998 [1781/87], A26/B42; also Winfield, 1998, pages 55, 60). ${ }^{21}$

\footnotetext{
${ }^{20}$ In addition to engaging with Kant's notion of space in his Encyclopedia, Hegel discussed Kant's and Locke's concepts of space in his Lectures on the History of Philosophy. On Kant, see Hegel (1986, pages 151-152/222-223). On Locke, see Hegel (1986, pages 118-119, 121/172-173, 176).

${ }^{21}$ Hegel referred to Kant's views of space in the Kritik der reinen Vernunft (1781/87). However, Kant understood space and time somewhat differently in earlier works (see Petry's translation of Hegel, 1970a I, page 306, editor's note). On the changes in Kant's views, see Elden (2009, pages 20-23). Hegel himself had expressed a slightly different view of space and time in his Phenomenology of Spirit (1970d, pages 82-93/59-66). There, he linked space
} 
In sum, whilst Hegel attributed characteristics such as fixity and continuity to space, he understood space as part of nature’s active dialectic (Hegel, 1992a, §§259-260; compare Houlgate, 2005, pages 110-112). He did not remove space and time from the dialectic, as Mann has suggested (Mann, 2008, pages 924-925). Time logically emerged from abstract space and negated it. Furthermore, abstract space exhibited a logical rather than temporal primacy over both "time” and nature’s subsequent "levels". Thus, while spirit logically comprehends space as nature's foundation and time's predecessor, in fact, space and time emerge simultaneously. For Hegel, then, space and time could not be pried apart (see Houlgate, 2005, pages 111-112; compare Hegel, 1970b, §448 Addition; 1992a, §§259-260). ${ }^{22}$

\section{Geography, anthropology and geo-history}

Hegel's discussion of history's 'geographical foundation' in his Lectures on the Philosophy of World History, and his discussion of geography's influence on spirit in his Philosophy of Spirit, helped concretize the more abstract discussion of space and time in his Philosophy of Nature. The Philosophy of Nature had demonstrated the ontological basis for humans' appearance in nature as spatial and temporal, while Hegel's geo-history and philosophy of spirit identified space and time’s empirical contours.

Strictly speaking, Hegel understood geography as 'physical geography’ (physische Geographie). He defined physical geography in the Philosophy of Nature's third part, 'organics', under the sub-heading 'geological nature', which concerned "the earth-body [Erdkörper] as a

and time to 'sense-certainty' (sinnliche Gewißheit). Later, in the Philosophy of Spirit, he distanced himself from his remarks in the Phenomenology (see Hegel, 1970a, §§418 Remark, 449-451; 2008, pages 438-442; 2011, pages 815822). Stone (2005) has argued, however, that in the Philosophy of Spirit, Hegel "simultaneously continues, obscurely, to connect them [i.e. sense-certainty, space and time]” (page 181 note 13).

${ }^{22}$ For further discussion of Hegel's understanding of space and time, see for example Hösle (1987); Winfield (1998); Stone (2005, pages 11-12, 38-40, 78). 
universal system of individual bodies” (1992a, §338). Physical geography concerned “the particular formations of the earth”, and particularly the earth's division into rivers, solid land, islands, valleys, mountains and continents, whose natural formation followed "purely mechanical” processes (1970a, §339 Addition).

In his Philosophy of Spirit, Hegel returned to physical geography and discussed humans' relationship to it. He treated human beings' relation to geography under the heading 'subjective spirit', which constituted the first and least concrete stage in the progression from subjective to objective to absolute spirit. More specifically, he discussed geography's relationship to humans under the sub-heading 'the natural soul' (die natürliche Seele), that is, spirit in its most basic condition. Spirit's manifestation as the natural soul, moreover, came under anthropology's purview. Unlike Kant, whose 'pragmatic anthropology' concerned "knowledge of the human being as a citizen of the world” (Kant, 1968a, pages 119-122), Hegel saw anthropology as concerned with the soul's "natural determination" (Naturbestimmtheit), its "natural condition" (Naturzustand) and "the natural differences among anthropological humans" (2008, page 34), which included differences among races and nations (2008, pages 28-62; 2011, pages 593745). ${ }^{23}$

Hegel discussed humans' connection to geography under the heading "the natural soul” because he believed geography influenced humans most at this early stage in spirit's development. As natural souls, humans have yet to set themselves apart from their immediate natural surroundings, including their geography. In this condition,

"spirit takes part in the universal planetary life, feels the difference of climates, the changes of the seasons, the periods of the day, etc., a natural life that in spirit [Geist]

\footnotetext{
${ }^{23}$ Scholars disagree over Hegel's definitions of 'race' (Rasse, Geschlecht), 'people' (Volk) and their conceptual interconection. In particular, see Bernasconi (2000, pages 187-188; 2011, page 326); Bonnetto (2006, pages 38-39).
} 
emerges only in occasional dark moods” (1992a, §392, trans. modified; compare 2011, pages 599-601).

The natural soul thus proves more susceptible to external influences such as climate and seasonal changes than in its more developed and self-conscious state as spirit.

Hegel linked the natural soul's determination to differences in physical geography. For him, “the natural differences among anthropological humans” corresponded to continental divisions and regional geographies. As he put it, anthropological humans’ variety is “necessarily constituted by place of residence [Aufenthalt]. This variety [Vielheit] further divides itself into great differences [große Unterschiede]; these differences are natural, and only natural, and as such, they relate to differences in the natural earth [die Unterschiede des Natürlichen Bodens]” (2008, page 34).

Hegel saw the earth's geographical differences as 'natural' because they related to human beings’ immediate natural environment. Large-scale geographical differences also prove 'natural' because they relate to human beings' 'natural condition' and their determination as 'natural souls'.

Crucially, Hegel viewed the large-scale divisions between continents and their vast subregions as ‘necessary' (notwendig) and 'essential' (wesentlich) rather than 'contingent' (zufällig) and 'arbitrary’ (willkürlich) (1970b, §393 Addition; 2008, pages 34, 231). Such geographical differences proved 'essential' and “necessary, because they correspond to the concept of thought” (1996, page 96). Moreover, he argued the three continents “are in an essential relationship and make up a rational totality” (page 96). Global geographical divisions arose naturally, and spirit necessarily understands them as 'natural' and 'essential' divisions in its path to freedom through reason. In short, Hegel aimed to elucidate the earth's essential divisions and 
their governing logic rather than to analyze particular regions and places (1970b, §393 Addition; 1983, §159).

Continents and vast regions with their natural and essential divisions served as the scalar building blocks for Hegel's geo-history of spirit. Continental divisions fundamentally rested on the split between the Old and New World, which Hegel characterized as "the basic division of the earth” (die Hauptunterscheidung der Erde) (1970, §393 Addition), as “a necessary diremption... which the world itself makes, rather than us” (1996, page 93), and as an “opposition” (Gegensatz) (2008, page 231; 2011, pages 605-606). ${ }^{24}$ In addition, he characterized the Old World as “completely self-determined [in sich volkommen determinirtes]”, whereas he argued the New World exhibited “only universal differences [allgemeine Unterschiede] between north and south” (2008, page 34).

Hegel divided the Old World into three ‘continents’ (Weltteile), namely Africa, Asia and Europe. To justify this 'essential' division, he invoked the ancients' geographical knowledge and reason itself. Whilst the ancients had already recognized the Old World's threefold division, their 'knowledge of nature' (Natursinn) alone proved insufficient to justify this partition. For Hegel, reason required the tripartite continental division, just as reason necessitated the division between the Old and New World (1996, page 96).

The Old World's tripartite division corresponded to an empirical geographical foundation as well. Drawing on Ritter's Erdkunde (1817, pages 8-15, 61-74), Hegel suggested that three geographical forms, namely the highlands, plains and coastal areas, defined the Old World's three 'continents' (Hegel, 1996, pages 97-113). Each continent contained highlands, plains and coastal areas, though Hegel argued that only one geographical characteristic or 'moment' defined

\footnotetext{
${ }^{24}$ Here, Hegel echoed his Berlin colleague Ritter (1817), who had argued that the New World served as the Old World's “true opposite on the earth” (wahren Gegensatz auf dem Erdganzen) (pages 8-15, quote at 9).
} 
a continent and its people. 'Africa proper' constituted an undifferentiated landmass dominated by highlands, whose geography corresponded to spirit in its undifferentiated, 'natural' form, that is, spirit in its 'immediate individuality’ (unmittelbare Individualität). Asia, characterized by an unmediated contrast between "fruitful, lush flatland and Schlammtäler", corresponded to spirit in its particularity (pages 101, 108). Finally, Europe displayed a more varied geography than Africa or Asia, with its mix of mountain chains, valleys, hills, and flatlands, which corresponded to spirit in in its concrete universality (pages 97-98). In Hegel’s geographical thought, differences in the 'character of spirit' thus corresponded to fundamental geographical characteristics (page 98).

Geography, race and climate

Hegel's discussion of humans' relation to their geography primarily focussed on race and climate. In both instances, Hegel displayed his geographical thought’s limitations. Indeed, his thoughts on race and climate highlight important contradictions and ambivalences in Hegel's reason-governed global geography.

For Hegel, natural geographical differences corresponded to racial differences. As he asserted in the Philosophy of Spirit,

““'The universal planetary life of the natural spirit particularizes itself into the concrete differences of the earth and breaks up into the particular natural spirits [besondern Naturgeister] which, on the whole, express the nature of the geographical regions of the world [geographischen Welttheile] and constitute the diversities of race [Racenverschiedenheit]” (1992a, §393, trans. modified; compare 1990b, page 224; 2011, page 605). 
Similarly, he argued, "national characters [Nationalcharactere] are more or less bound to countries [Länder]", and that "they constitute the specific differences of race" and the “characteristics of the spirits of races” (Characterische des Geistigen der Racen) (2008, pages 29-39, also 234-239; 2011, page 605). Geographical differences between continents mattered for racial differences at spirit's most basic level, the natural soul.

Hegel, however, failed to explain precisely how geographical differences 'express' (ausdrücken) and 'constitute' (ausmachen) racial differences and differences in national character. In his lectures on subjective spirit, he suggested that climate influenced skin colour in Africa (2008, page 236), though elsewhere he suggested skin colour resulted from "the free activity of the blood" (2011, page 607). ${ }^{25}$ He offered no further explanation for precisely how continents' geographical characteristics influenced racial characteristics (2008, pages 234-239; 2011, 607-608; cf. 1970b, §393 Addition). Hegel’s failure to do so is not surprising, given that unlike Montesquieu in his De l'esprit des lois (1748), Hegel showed little interest in outlining how geography influenced a peoples’ national character and laws through physiological causes. ${ }^{26}$ Hegel's remarks on geography's relation to race prove rather 'cryptic', as Hoffheimer has suggested (Hoffheimer, 2001, pages 41-42). Even commentators who have emphasized biology’s significance in Hegel's thinking about race have failed to explain geography's influence on different races’ physiological traits (Mollendorf, 1992, pages 245-246; Lettow, 2013, page 127), precisely because Hegel himself failed to do so. Thus, as David Krell has argued, "precisely how

\footnotetext{
${ }^{25}$ Pointing to 'the Arabs' (die Araber) as an example, Hegel also argued that "the unalterability of the climate, the entire condition of the land, in which a nation has its fixed residence, contributes to the unalterability of character itself [Die Unveränderlichkeit des Klimas, der ganzen Beschaffenheit des Landes, in welchem eine Nation ihren bleibenden Wohnsitz hat, trägt zur Unveränderlichkeit des Charakters derselben bei]” (1970b, §394 Addition). He went on to discuss the importance of the sea's proximity for a peoples' character, though again he only vaguely linked geography with nations, races and their 'character' (1907b, §394 Addition; compare 1996b, pages 96-97; 2000, page 148; 2008, page 39; 2009, §247).

${ }^{26}$ However, in line with Montesquieu, Hegel argued, "the geographical principle [geographisches Prizip] makes a great difference in the constitutions of peoples who lives in different climates [Himmelsstrichen], necessarily, since climate has such great influence” (1983, §136, trans. modified, emphasis added).
} 
geography can determine the (un)spiritual character of a people who are members of one race, the human, remains mysterious in Hegel’s system” (Krell, 2000, page 125, also 123-124).

Hegel faced conceptual and empirical difficulty when he treated climate's significance in history as well. On one side, he accorded climatic conditions a strong, determining role. He argued that humans 'belong' to, or are 'bound' to, a given climate (1996, pages 92, 98; 2008, page 221). He supported the well-established view, already found in Aristotle’s Politics (1327b, 20-35), that the temperate zone allowed human cultures to flourish, while the torrid and frigid zones hindered cultural development and the "accomplishment of human aims” (2008, page 231). Geographical conditions in the extreme zones, for example in Siberia and sub-Saharan Africa, prevent spirit from fashioning “a world for itself” (1996, pages 92-93, also 102; 2009, §270). Thus, in sub-Saharan Africa, Geist "remains identical with nature" and "bound" to this region’s “physical determination” (physische Bestimmung) (1996, pages 92, 98; cf. Ritter, 1817, pages 12-13, 77-424). Here, nature's force (Naturgewalt) and the "external power of the elements" hindered peoples' ability to move beyond the 'natural soul' to a higher phase of consciousness (1996, page 92; 2008, page 231).

At the same time that Hegel granted climatic conditions a determining role in the extreme zones, he refrained from giving climatic conditions universal primacy over spirit’s cultural development. As he argued in his 1822/23 Lectures on the Philosophy of World History: "Climate $[$ Klima $]$ is a completely abstract, general moment in relation to spirit’s form. History lives off the ground [Boden] of necessity, but this is only one side, the higher side being that of Spirit. Nature is therefore a moment with little influence. The natural side of existence, climate, does not itself extend to the individual [Individuen]. Thus, it is boring 
to hear about the Ionian, mild sky in relation to Homer. Indeed, though the sky is mild, the

Turks have no Homer” (1996,page 92; 2008, page 231; 2011, page 600). ${ }^{27}$

He likewise found it "unsatisfying” to cite "the Ionian climate as the cause of Homer's work, or Caesar's ambition as the cause of Rome's republican constitution’s downfall” (1992b, page 400; compare 1955, page 241/195-196). ${ }^{28}$ For Hegel, then, external causal factors such as climate exert more influence on the 'natural soul' than on developed, self-conscious spirit, for whom such factors remain secondary (compare Inwood, 1983, pages 438-439).

Hegel's ambiguous view of geography's influence on race and climate has implications for how he understood freedom and its historical geography. Scholars such as Houlgate and McCarney have argued that Hegel's view of human freedom prevented him from permanently foreclosing access to freedom even for peoples in extreme climatic zones, such as Africans (Houlgate 2005, pages 174-175; McCarney, 2000, pages 144-145; also see Bonetto, 2006). Such a foreclosure contradicts "the universalism of his philosophy of spirit with its central themes of freedom as the birthright of all human beings as bearers of spirit and of history as the process by which it is won for them” (McCarney, 2000, page 145), along with Hegel's view that “mankind's natural constitution and specific historical and geographical context, while providing the conditions from which we must start, do not fix for all time what human beings can become” (Houlgate, 2005, page 14). Indeed, Houlgate (2005) has argued that Hegel saw a people’s level of "self-consciousness and self-understanding”, rather than their physical geography, as the key determinants of their “outlook and character” (page 22).

\footnotetext{
${ }^{27}$ Hegel probably referred to the Englishman Robert Wood's argument for climate's influence on Homer's work in his On the Original Genius and Writings of Homer (1769). A German translation of Wood's book appeared in 1773 and influenced many, including Alexander von Humboldt, who remarked in his Ideen zu einer Physiognomik der Gewäsche (1806), "How powerfully has the Greek sky influenced its inhabitants!” (page 13). I owe the Humboldt reference to Hartshorne (1939, page 80).

${ }^{28}$ Hegel's emphasis on a people's ability to overcome nature's force bore some resemblance to the Greek historian Polybius’s ideas. On Polybius, see Glacken (1967, pages 95-96).
} 
Hegel might have held open the potential for all cultures peoples to progress beyond their immediate sensuous state in nature, regardless of geography's immediate constraints on them. However, Hegel's discussion of Africa proper demonstrates that an otherwise unhistorical people required Europeans' assistance to achieve greater self-consciousness (Bernasconi, 1998, pages 61-62). Africans lacked their own 'inner tendency to culture' (inneren Trieb zur Kultur) (Hegel, 1970b, §394 Addition), but they could advance to a higher level if, for example, they migrated to Africa's coastal regions and adopted local European merchants' and colonialists' cultural sensibilities. Hegel's argument here rested on certain colonialist assumptions. More than that, his argument that Africans could cultivate themselves in Africa required him to "forget" his “arguments about the constraints of climate”, as Bernasconi (1998, pages 62) has argued (cf. Mussett, 2003, page 10). Indeed, whilst Africa proper’s torrid heat worked to keep Africans mired in an uncultivated state, they could nevertheless 'cultivate' themselves with Europeans' assistance while still in torrid Africa.

Hegel's remarks on spirit's relationship to race and climate highlight a tension in Hegel's geo-history of spirit. His refusal to map spirit’s historical geography according to a strict geographical determinism, his inability to explain geography's precise relationship to racial differences, and his decision to construct a world regional geography based primarily on reason rather than empirical geographical data, show that geography had a complicated and contradictory role in Hegel's philosophical system. Where, though, does the state's relationship to its geography figure into Hegel’s conflicted geographical thought? 


\section{Hegel on the state and territory}

Territory marks a curious omission in Hegel’s geographical thought. Hegel’s omission of territory is curious not because Hegel should have discussed it, but because the modern concept of territory had already become established by Hegel's time (see Elden, Forthcoming). That his lectures on the philosophy of history and subjective spirit lack a discussion of territory is perhaps understandable, given his concern with explaining the world’s 'essential', large-scale geographical divisions. But territory is also conspicuously absent from his Philosophy of Right, the centrepiece of Hegel's political philosophy, which explains spirit's rational progression toward the political arrangement that most fully embodies its freedom: 'the state' (der Staat).

At certain junctures in the Philosophy of Right, Hegel alluded to the state's relation to territorial entities. For example, when he described the transition from 'civil society' (bürgerliche Gesellschaft) to the state, he argued, "town and country...make up, in general, the two still ideal moments from which the state emerges as their true ground [Grund]” (2009, §256, trans. modified). When he discussed the state’s 'internal constitution’ (das Innere Staatsrecht), he noted, "the inward aspect of the state as such is its civil power [Zivilgewalt], and its outward aspect is its military power [Militärgewalt]”, but asserted no direct link between the state's 'civil power’ and its territory (1970c, §271 Addition, trans. modified). He referred to “the state’s power over everything individual and particular, over life and property”, and to its status as an “absolute power on earth” (absolute Macht auf Erden), but again remained silent on the state’s power over its territory (2009, §323, emphasis in original). ${ }^{29}$ Further, he omitted territory when he discussed sovereignty and states’ relations with one another (2009, §§273-340), though he noted in passing that states’ 'extent’ (Umfang) mattered in international relations (1983, §161).

\footnotetext{
${ }^{29}$ However, Hegel referred to public monuments as ‘national property’ (National-Eigenthum) (2009, §64 Remark).
} 
Despite the state-territory link's absence in Hegel's work, some scholars have nevertheless asserted this link’s importance. In particular, Lefebvre argued that, “according to Hegelianism, historical time gives birth to that space which the state occupies and rules over” (2000 [1974], page 29/21, emphasis added). He further contended that

"time, dominated by repetition and circularity, overwhelmed by the establishment of an immobile space [espace immobile] which is the locus [lieu] and environment [milieu] of realized Reason...loses all meaning” (page 30/21).

Lefebvre referred to "the Hegelian view of space as product and residue of historical time" (page 30/22, emphasis added), and similarly argued, "For Hegel space brought historical time to an end, and the master of space was the state. Space perfected the rational and the real -simultaneously” (page 321/279, emphasis added). The state unquestionably occupied a central place in Hegel's philosophy. Yet, to suggest that Hegel "reified and fetishized space in the form of the territorial state” (Soja 1989, page 86) is misleading.

Hegel nowhere valorized space or the state’s geographical territory in the way Lefebvre and Soja have suggested. He referred to the state as an "absolute and unmoved end in itself [absoluter unbewegter Selbstzweck]” (Hegel, 2009, §258), but not as an “immobile space” (espace immobile), as Lefebvre claimed (2000 [1974], page 30/21). Hegel’s interest lay in geography’s relationship to a peoples' national character and race, rather than territory understood as a bounded, legal-political entity ruled over by the state.

If Hegel understood the state as 'the master of space' (maitre l'Etat), Lefebvre failed to ground this claim in Hegel's work. Lefebvre's inclination to make claims without any basis in Hegel's work stemmed in part from his equivocation in his use of the terms 'Hegel' and 'Hegelianism’ (2000 [1974], page 29/21). While representatives of ‘Hegelianism’ might have 
claimed that Hegel erected a state space in his political philosophy, Hegel's own work suggests otherwise.

Why, then, did Hegel omit territory from his political philosophy? Two reasons present themselves, one conceptual and one concrete. First, Hegel might have omitted territory because he wanted to explain the state's development philosophically rather than historically. Scattered references to historical examples appeared in his text, yet, for Hegel, such examples alone proved insufficient to ground a scientifically adequate political philosophy. His interest in “scientific cognition” (wissenschaftliches Erkennen) trumped any concern with the "historical origin of the state in general” (2009, §258).

The second and perhaps more important reason Hegel avoided discussing the state’s relation to territory stemmed from his own experience of place and politics in the Holy Roman Empire. Hegel saw 'particularism' as an impediment to the modern bureaucratic state’s effective operation in the post-Napoleonic period. Particularism, namely the "communal policing of personal morality and livelihood” that defined average Germans’ communal ties and geographical sensibility for much of the early modern period, had survived into the nineteenth century. In Hegel's view, particularism stood at odds with “modernizing needs” such as labour mobility and marital freedom, which he saw as necessary conditions for a community's rational organization. At the same time, Hegel, himself a product of Württemberg particularism, understood the importance of place for Germans, and thus tried to integrate individuals' place attachment and "hometown and particularist emotions” into a more "rational community structure” that was compatible with "the aims of a modern civil society and state” (Pinkard, 2000, pages 605-609, also see 469-470; Hegel, 2009, §§142-246). 


\section{Towards an historical geography of Hegel's geographical thought}

Until now, geographers have shown little interest in Hegel’s geographical thought. Most geographers have engaged with Hegel through Marx, or through Marxist and postcolonial scholars’ readings of Hegel. In this paper, I have outlined geographers' varied engagements with Hegel and tried to sketch out the contours of Hegel's geographical thought. Moreover, I have tried to show that Hegel's geographical concepts of space, continents, race, climate, which appeared in his philosophies of nature, spirit, and world history, must be understood in relation to each other and to his broader philosophical system. Indeed, space, continental divides and continents' material geographical characteristics figured in the Philosophy of Nature, but they necessarily reappeared in the Philosophy of Spirit. Hegel's discussion of spirit's spatio-temporal character and physical geography’s effect on racial variety, 'national character' and peoples' historical--or unhistorical--trajectory rested precisely on the categories such as space, time and organic life that Hegel had set out in the Logic and Philosophy of Nature.

At the same time that I have tried to systematize Hegel's geographical thought, I have also tried to point up certain ways in which Hegel’s geographical thought generates contradictions that haunt his philosophical system. In particular, I have shown that Hegel’s conflicted understanding of geography’s influence on 'anthropological humans’ complicated his conception of human freedom, as well as his grasp of the geography of freedom in the Old and New Worlds. Moreover, I have suggested that Hegel's conception of nature, space, and geography mattered not only for his 'geo-history’ and philosophies of nature and subjective spirit, but for his understanding of modernity’s geography as well.

If grasping the full breadth of Hegel's geographical thought requires a careful engagement with Hegel's texts, it likewise requires a more detailed study of the local and global geographies 
that informed Hegel's geographical thought. This would entail studying how Hegel's experiences of place and power in Württemberg, Heidelberg, Jena and Berlin shaped his thinking about communities' and the states' relationship to place and territory. It would also entail studying how Hegel's geographical knowledge influenced his thinking about current events, and more particularly geography’s significance in current events. Buck-Morss’s (2000; 2009) work on “Hegel and Haiti” might provide a rough guide here, even though geography is conspicuously absent in her analysis of an inherently geographical phenomenon, namely slavery. Further, a more detailed geographical study would entail a closer analysis of Hegel's personal and intellectual ties with Carl Ritter and Alexander von Humboldt, along with Berlin’s significance for these scholars as a place of scientific knowledge creation. Taken together, these studies would constitute a comprehensive historical geography of Hegel's geographical thought, which would illuminate how Hegel both lived and conceived the geographies of modernity. While a detailed historical geography of Hegel's geographical thought remains to be written, this paper marks a first step towards its realization.

Acknowledgements. I thank the panelists and audience members who commented on an early draft of this paper presented at the 2011 Association of American Geographers annual meeting in New York. I am especially grateful to Matthew Farish and Stuart Elden for their comments on earlier drafts. Finally, I thank this journal's anonymous referees, whose generous reviews and critical prodding helped me sharpen the paper.

\section{References}

Anunchin V A, 1977 [1960] Theoretical Problems in Geography Trans. R J Fuchs, G J Demko (Ohio State University Press, Columbus, $\mathrm{OH}$ )

Avineri S, 1972 Hegel's Theory of the Modern State (Cambridge University Press, Cambridge) 
Beck H, 1973 Geographie. Europäische Entwicklung in Texten und Erläuterungen (K. Alber, Freiburg)

Bernasconi R, 1998, "Hegel at the court of Ashanti”, in Hegel after Derrida Ed. S Barnett

(Routledge, London) pp 41-63

Bernasconi R, 2000 "With what must the philosophy of history begin? On the racial basis of

Hegel’s Eurocentrism” Nineteenth-Century Contexts 22 171-201

Bernasconi R, 2003, “Hegel's racism: a reply to McCarney” Radical Philosophy 119 32-37

Bernasconi R, 2011, “'The ruling categories of the world': the trinity in Hegel's philosophy of

history and he rise and fall of peoples”, in A Companion to Hegel, Eds S Houlgate, M

Baur (Blackwell, Oxford) pp 315-331

Bonetto S, 2006, "Race and racism in Hegel -- an analysis” Minerva - An Internet Journal of Philosophy 10 35-64

Buck-Morss S, 2000, “Hegel and Haiti” Critical Inquiry 26 821-865

Buck-Morss S, 2009 Hegel, Haiti and Universal History (University of Pittsburgh Press, Pittsburgh)

Burgess R, 1978, “The concept of nature in geography and Marxism” Antipode 10 1-11

Casey E S, 1997 The Fate of Place: A Philosophical History (University of California Press, Berkeley)

Castree N, 1996, "Birds, mice and geography: Marxisms and dialectics”, Transactions of the Institute of British Geographers 21 342-362.

Collinge C, 2008, "Positions without negations? Dialectical reason and the contingencies of space” Environment and Planning A 40 2613-2622

Dickinson R E, 1969 The Makers of Modern Geography (Routledge, London)

Driver F, 1992, “Geography's empire: histories of geographical knowledge” Environment and Planning D: Society and Space 10 23-40

Elden S, 2004, Understanding Henri Lefebvre: Theory and the Possible (Continuum, London)

Elden S, 2008, "Dialectics and the measure of the world” Environment and Planning A 40 $2641-2651$

Elden S, 2009, “Reassessing Kant’s geography” Journal of Historical Geography 35 3-25

Elden S, Forthcoming, The Birth of Territory (University of Chicago Press, Chicago)

Elden S, Mendieta E (Eds), 2011 Reading Kant's Geography (SUNY Press, Albany)

Gerbi A, 2010 [1955] The Dispute of the New World: The History of a Polemic, 1750-1900

Trans. Jeremy Moyle (University of Pittsburgh Press, Pittsburgh)

Gidwani V, 2008, “The subaltern moment in Hegel's dialectic” Environment and Planning A 40 $2578-2587$

Glacken C J, 1967 Traces on the Rhodian Shore: Nature and Culture in Western Thought from Ancient Times to the End of the Eighteenth Century (University of California Press, Berkeley)

Gregory D, 1994 Geographical Imaginations (Blackwell, Cambridge, Mass.)

Gregory D, 1998, "Power, knowledge and geography” Geographische Zeitschrift 86 70-93

Günzel S, 2002, "Philosophische Geographien. Nietzsche und Hegel”, in Hegel-Jahrbuch, Phänomenologie des Geistes, 2. Teil, Eds A Arndt, K Bal, H Ottmann (Akademie Verlag, Berlin) pp 294-302

Hartshorne R, 1939 The Nature of Geography: A Critical Survey of Current Thought in the Light of the Past (American Association of Geographers, Lancaster, PA)

Harvey D, 1981, “The spatial fix: Hegel, von Thünen, Marx” Antipode 13 1-12 
Harvey D, 1996 Justice, Nature and the Geography of Difference (Blackwell, Oxford)

Harvey D, 1999, “On fatal flaws and distractions” Progress in Human Geography 23 557-566

Harvey D, 2006 [1982] The Limits to Capital (Verso, London)

Hegel G W F, 1955 Vorlesungen über die Philosophie der Weltgeschichte, Bd. I, Die Vernunft in der Geschichte Ed. J Hoffmeister (Felix Meiner, Hamburg) Translated as Lectures on the Philosophy of World History. Introduction: Reason in History Trans. H B Nisbet (Cambridge University Press, Cambridge, 1975)

Hegel G W F, 1961 Briefe von und an Hegel, 4 Bde. Ed. J Hoffmeister (Felix Meiner, Hamburg) Translated in part as Hegel: The Letters Trans. C Butler, C Seiler (Indiana University Press, Bloomington, 1984)

Hegel G W F, 1970a Enzyklopädie der philosophischen Wissenschaften im Grundrisse (1830), 2. Teil, Die Naturphilosophie [Werke; Bd. 9] (Suhrkamp, Frankfurt a.M.)

Translated as Hegel's Philosophy of Nature, 3 vols. Trans. and Ed. M J Petry (George Allen and Unwin, London)

Hegel G W F, 1970b Enzyklopädie der philosophischen Wissenschaften im Grundrisse (1830), 3. Teil, Philosophie des Geistes [Werke; Bd. 10] (Suhrkamp, Frankfurt a.M.) Translated as Hegel's Philosophy of Mind Trans. W Wallace, A V Miller, with revisions and commentary by M J Inwood (Clarendon Press, Oxford, 2007)

Hegel G W F, 1970c Grundlinien der Philosophie des Rechts [Werke; Bd. 7] (Suhrkamp, Frankfurt a.M.) Translated as Elements of the Philosophy of Right Ed. A Wood, Trans. H B Nisbet (Cambridge University Press, Cambridge, 1991)

Hegel G W F, 1970d Phänomenologie des Geistes [Werke; Bd. 3] (Suhrkamp, Frankfurt a.M.) Translated as Phenomenology of Spirit Trans. A.V. Miller (Clarendon Press, Oxford, 1977)

Hegel G W F, 1983 Vorlesungen über Naturrecht und Staatswissenschaft. Heidelberg 1817/18 mit Nachträgen aus der Vorlesung 1818/19. Nachgeschr. von P Wannenmann, Eds C Becker et al. [Vorlesungen; Bd. 1] (Hamburg, Felix Meiner) Translated as Lectures on Natural Right and Political Science. The First Philosophy of Right. Heidelberg 1817-1818 with Additions from the Lectures of 1818-1819 Trans. J M Stewart, P C Hodgson (University of California Press, Berkeley, 1996)

Hegel G W F, 1986 Vorlesungen über die Geschichte der Philosophie, Teil 4, Philosophie des Mittelalters und der neueren Zeit Eds P Garniron, W Jaeschke [Vorlesungen; Bd. 9] (Felix Meiner, Hamburg) Translated as Lectures on the History of Philosophy (1825/26). Vol III: Medieval and Modern Philosophy Ed. R F Brown, Trans R F Brown, J M Stewart (University of California Press, Berkeley, 1990)

Hegel G W F, 1990b Schriften und Entwürfe I (1817-1825) Eds F Hogemann, C Jamme [Gesammelte Werke; Bd. 15] (Felix Meiner, Hamburg)

Hegel G W F, 1992a Enzyklopädie der philosophischen Wissenschaften im Grundrisse (1830)

Eds W Bonsiepen, H-C Lucas [Gesammelte Werke; Bd. 20] (Felix Meiner, Hamburg)

Hegel G W F, 1992b Wissenschaft der Logik. Die Lehre vom Wesen (1813) Ed. H-J Gawoll [Gesammelte Werke; Bd. 11] (Felix Meiner, Hamburg)

Hegel G W F, 1996 Vorlesungen über die Philosophie der Weltgeschichte, Berlin 1822/1823, nachgeschrieben von K G J von Grisheim, H G Hotho, F C H V von Kehler, Eds K H Ilting, K Brehmer, H N Seelmann [Vorlesungen; Bd. 12] (Felix Meiner: Hamburg)

Hegel G W F, 2000 Vorlesungen über die Philosophie des Rechts, Berlin 1819/1820, nachgeschrieben von J R Ringier, Eds E Angehrn, M Bondelli, H N Seelmann H N 
[Vorlesungen; Bd. 14] (Felix Meiner, Hamburg)

Hegel G W F, 2002 Vorlesungen über die Philosophie der Natur. Berlin 1819/20 Nachgeschr. von J R Ringier, Eds M Bondelli, H N Seelmann [Vorlesungen; Bd. 16] (Felix Meiner, Hamburg)

Hegel G W F, 2006 Nürnberger Gymnasialkurse und Gymnasialreden (1808-1816) Ed. K Grotsch [Gesammelte Werke; Bd. 10/1] (Felix Meiner, Hamburg)

Hegel G W F, 2007 Vorlesungen über die Philosophie der Natur. Berlin 1825/26. Nachgeschr. von H W Dove Eds K Bal, G Marmasse, T Siegfried, K Vieweg [Vorlesungen; Bd. 17] (Felix Meiner, Hamburg)

Hegel G W F, 2008 Vorlesungen über die Philosophie des subjektiven Geistes (1822-25)

Ed. C J Baur [Gesammelte Werke; Bd. 25/1] (Felix Meiner, Hamburg)

Hegel G W F, 2009 Grundlinien der Philosophie des Rechts [1821], Eds K Grotsch, E WeisserLohmann [Gesammelte Werke; Bd. 14/1] (Felix Meiner, Hamburg)

Hegel G W F, 2011 Vorlesungen über die Philosophie des subjektiven Geistes (1827/28) Ed. C J Baur [Gesammelte Werke; Bd. 25/2] (Felix Meiner, Hamburg)

Hirschman A O, 1976, “On Hegel, imperialism and structural stagnation” Journal of Development Economics 3 1-8

Hoffheimer M H, 2001, "Hegel, race, genocide” The Southern Journal of Philosophy 39 35-62 Hoffheimer M H, 2005, "Race and racism in Hegel's philosophy of religion”, in Race and Racism in Modern Philosophy Ed. A Valls (Cornell University Press, Ithaca, NY) pp $194-216$

Hösle V, 1987, “Raum, Zeit, Bewegung”, in Hegel und die Naturwissenschaften Ed. M J Petry (Frommann, Stuttgart-Bad Canstatt), pp 247-292

Houlgate S, 2005 An Introduction to Hegel: Freedom, Truth and History, 2nd ed. (Blackwell, Oxford)

Humboldt A v, 1806 Ideen zu einer Physiognomik der Gewäsche (Cotta’sche Buchhandlung, Tübingen)

Humboldt A v, 1860 Briefe von Alexander von Humboldt an Varnhagen von Ense aus den Jahren 1827 bis 1858, nebst Auszügen aus Varnhagen's Tagebüchern, und Briefen von Varnhagen und Andern an Humboldt, 4. Aufl. Ed. L Assing (F.A. Brockhaus, Leipzig). Translated as Letters of Alexander von Humboldt to Varnhagen von Ense from 1827 to 1858, with Extracts from Varnhagen's Diaries, and Letters of Varnhagen and others to Humboldt Trans. F Kapp (Rudd \& Carleton, New York, 1860)

Innerarity D, 1992, “Hegels Idee von Europa” Zeitschrift für philosophische Forschung 46 381-394

Inwood M J, 1983 Hegel (Routledge, London)

Jenkins S, 2010, “Hegel on space: a critique of Kant's transcendental philosophy” Inquiry 53 326-355

Jones A, 1999, “Dialectics and difference: against Harvey's dialectical Marxism” Progress in Human Geography 23 529-555

Kant I, 1968a Anthropologie in pragmatischer Hinsicht [Akademie-Textausgabe; Bd. 7] (de Gruyter, Berlin) pp 119-333.

Kant I, 1968b Grundlegung zur Metaphysik der Sitten [Akademie-Textausgabe; Bd. 4] (de Gruyter, Berlin) pp 385-463

Kant I, 1998 [1781/87] Kritik der reinen Vernunft (Felix Meiner, Hamburg) 
Kant I, 2009 Vorlesungen über Physische Geographie, Ed. W Stark [Gesammelte Schriften; Bd. 26] (de Gruyter, Berlin)

Krell D F, 2000, "The bodies of black folk: From Kant and Hegel to Du Bois and Baldwin” boundary 27 103-134

Lefebvre H, 2000 [1974] La production de l'espace 4e édition (Anthropos, Paris) Translated as The Production of Space Trans. D Nicholson-Smith (Blackwell, Oxford, 1991)

Livingstone D N, 1992 The Geographical Tradition: Episodes in the History of a Contested Enterprise (Blackwell, Oxford)

Livingstone D N, 2002, “Race, space and moral climatology: notes toward a genealogy” Journal of Historical Geography 28 159-180

Mann G, 2008, “A negative geography of necessity” Antipode 40 922-934

Martin G J, 2004 All Possible Worlds: A History of Geographical Ideas, 4th ed. (Oxford University Press, Oxford)

May J A, 1970 Kant's Concept of Geography and its Relation to Recent Geographical Thought (University of Toronto Press, Toronto)

McCarney J, 2000 Hegel on History (Routledge, New York)

McCarney J, 2003, “Hegel's Racism? A Response to Bernasconi” Radical Philosophy 119 32-5.

Mollendorf D, 1992, "Racism and rationality in Hegel's Philosophy of Subjective Spirit” History of Political Thought 13 243-255

Mussett S M, 2003, "On the threshold of history: the role of nature and Africa in Hegel's philosophy”, in Tensional Landscapes: The Dynamics and Boundaries of Placements Eds G Backhaus, J Murungi (Lexington Books, Lanham, Md.) pp 1-18

Negebauer C, 1990 “The racism of Hegel and Kant”, in Sage Philosophy Ed. H Odera Oruka, (Brill, Leiden) pp 259-270

Neuser W, 1987, "Die Naturphilosophische und naturwissenschaftliche Literatur aus Hegels privater Bibliothek”, in Hegel und die Naturwissenschaften Ed. M J Petry

(Frommann, Stuttgart-Bad Canstatt), pp 479-499

Parekh S, 2009, “Hegel’s New World: history, freedom, and race”, in Hegel and History Ed. W Dudley (SUNY Press, Albany) pp 111-131

Peet R, 1985, “The social origins of environmental determinism” Annals of the Association of American Geographers 75 309-333

Peet R, 1998 Modern Geographical Thought (Blackwell, Oxford)

Pinkard T, 2000 Hegel: A Biography (Cambridge University Press, Cambridge)

Petry M J, 1981, “Hegels Naturphilosophie: die Notwendigkeit einer Neubewertung” Zeitschrift für philosophische Forschung 35 614-628.

Purtschert P, 2010, “On the limit of spirit: Hegel’s racism revisited” Philosophy \& Social Criticism 36 1039-1051.

Ratzel F, 1882 Anthropo-Geographie oder Grundzüge der Anwendung der Erdkunde auf die Geschichte (J. Engelhorn, Stuttgart)

Ritter C, 1817 Die Erdkunde im Verhältniß zur Natur und zur Geschichte des Menschen, oder allgemeine vergleichende Geographie, als sichere Grundlage des Studiums und Unterrichts in physikalischen und historischen Wissenschaften, Erster Theil, Erstes Buch, Afrika (G. Reimer, Berlin)

Roberts J M, 2001, "Realistic spatial abstraction? Marxist observations of a claim within critical realist geography” Progress in Human Geography 25 545-567 
Rosenkranz K, 1963 [1844] Georg Wilhelm Friedrich Hegels Leben (Wissenschaftliche Buchgesellschaft, Darmstadt)

Ruddick S M, 2008, “Towards a dialectics of the positive” Environment and Planning A 40 $2588-2602$

Ruddick S M, 2011, “A dialectics of encounter” Environment and Planning D: Society and Space 29213 - 222

Sass, H-M, 1973, "Die philosophische Erdkunde des Hegelianers Ernst Kapp. Ein Beitrag zur Wissenschaftstheorie und Fortschrittsdiskussion in der Hegelschule" Hegel-Studien 8 163-181

Schwind M, 1960, “Die Geographischen ‘Grundlagen’ der Geschichte bei Herder, Hegel und Tonybee" Erdkunde 14 3-10.

Sheppard E, 2008, “Geographical dialectics?” Environment and Planning A 40 2603-2612

Sinnhuber K A, 1959, “Carl Ritter 1779-1859” Scottish Geographical Magazine 75 153-163

Smith N, 2008 [1984] Uneven Development: Nature, Culture, and the Production of Space 3rd ed. (University of Georgia Press, Athens)

Soja E W, 1989 Postmodern Geographies: The Reassertion of Space in Critical Social Theory (Verso, London)

Soja E W, 1996 Thirdspace: Journeys to Los Angeles and Other Real-and-Imagined Places (Blackwell, Oxford)

Stark W, 2011, "Kant's lectures on 'physical geography': a brief outline of its origins, transmission, and development: 1754-1805”, in Reading Kant's Geography Eds S Elden, E Mendieta (SUNY Press, Albany) pp 69-85

Stederoth D, 2001 Hegels Philosophie des subjektiven Geistes. Ein komparatorischer Kommentar (Akademie Verlag, Berlin)

Stone A, 2005 Petrified Intelligence: Nature in Hegel's Philosophy (SUNY Press, Albany)

Walsh W H, 1971 "Principle and prejudice in Hegel's philosophy of history”, in Hegel's Political Philosophy: Problems and Perspectives Ed. Z A Pelczynski (Cambridge University Press, Cambridge) pp 181-198

Winfield R N, 1998, "Space, time and matter: conceiving nature without foundations", in Hegel and the Philosophy of Nature Ed. Stephen Houlgate (SUNY Press, Albany), pp 51-69 